\title{
Natural and anthropogenic changes in the environment during the Holocene at the Kraków region (Southern Poland) from study of mollusc assemblages
}

\author{
Witold Paweł ALEXANDROWICZ ${ }^{1, *}$ \\ $1{ }^{1}$ AGH University of Science and Technology, Faculty of Geology, Geophysics and Environment Protection, Chair of Gen- \\ eral Geology and Geotourism, al. A. Mickiewicza 30, 30-059 Kraków, Poland
}

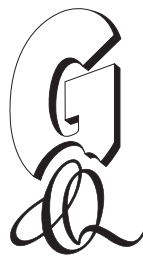
Alexandrowicz, P., 2021. Natural and anthropogenic changes in the environment during the Holocene at the Kraków region
(Southern Poland) from study of mollusc assemblages. Geological Quarterly, 65: 9, doi: 10.7306/gq.1577

Associate Editor: Wojciech Granoszewski

Malacological analysis was used to reconstruct Holocene environmental changes from profiles of calcareous tufa and fluvial deposits exposed in the Kobylanka Stream Valley, several kilometres west of Kraków in southern Poland. The abundant and diversified mollusc fauna was characterized by clear variability within the vertical succession where five types of molluscan assemblages were distinguished. The pattern of sedimentary and molluscan facies allowed characterization of two main intervals of environmental change during Holocene. In the lower interval, until the end of the Middle Holocene, human activity was not detected and environmental processes were controlled by natural factors. In the upper interval, corresponding to the Late Holocene, human impact can be seen, in the form of rapid deforestation and agricultural development. Anthropogenic impact has been particularly evident during the last millennium. The mollusc assemblages studied allowed accurate reconstruction of natural and anthropogenic factors affecting the natural environment.

Key words: mollusc assemblages, environmental changes, anthropogenic pressure, Holocene, southern Poland.

\section{INTRODUCTION}

Molluscs are sensitive indicators of environmental conditions, enabling reconstruction of changes of habitats and ecosystems whether under the influence of natural factors, especially climate, or those resulting from human activity. Snail and bivalve shells may commonly be found in Quaternary deposits. The ability for a shell to be preserved in the subfossil state is determined by many factors, most importantly the presence of calcium carbonate in the sediment. Because of low susceptibility to redeposition, molluscs are normally used for reconstruction of local environments and microhabitats.

Malacological research in the Kraków region, especially in the southern part of the Kraków-Częstochowa Upland, has a long history. Many localities of mollusc-bearing Quaternary deposits such as calcareous tufa (e.g., Alexandrowicz, 1983, 1997, 2004; Gradziński et al., 2017) and fluvial deposits (e.g., Alexandrowicz, 1991; Alexandrowicz et al., 1997) have been described from this area. The results obtained allowed reconstruction of environmental changes due to natural processes and evaluation of the human factor in shaping the environment.

\footnotetext{
*E-mail: wpalex@geol.agh.edu.pl
}

Received: September 7, 2020; accepted: November 27, 2020; first published online: February 15, 2021
Anthropogenic pressure related to increasing human population had a significant impact at the Kraków-Częstochowa Upland, though its intensity was uneven. It is mostly observed in areas with gentle terrain advantageous to the human economy. The main indicators of human impact were rapid deforestation and hydrological changes. Over a short time these phenomena resulted in significant deterioration of faunal and floral assemblages and had a major impact on geological processes, mainly on slopes and in rivers.

The successions discussed in this paper demonstrate environmental changes at the southern edge of the KrakówCzęstochowa Upland during the Holocene. Malacological analysis allows characterization of natural and anthropogenic influences on the environment, and enables palaeogeographic reconstruction, including restoration of features of local habitats and their correlation across larger geographic regions. The latter aspect is important, as it shows how local factors may significantly modify regional climatic and environmental trends.

\section{REGIONAL SETTING}

The study area is located in the southern part of the Kraków-Częstochowa Upland, 10 km west of Kraków near the village of Kobylany (Fig. 1). The upland is built of Mesozoic rocks: Middle Triassic and Upper Jurassic limestones, while Upper Paleozoic limestones play a minor role. The Mesozoic succession was subjected to slight tectonically-caused interruption at the Cretaceous/Paleogene transition, with develop- 


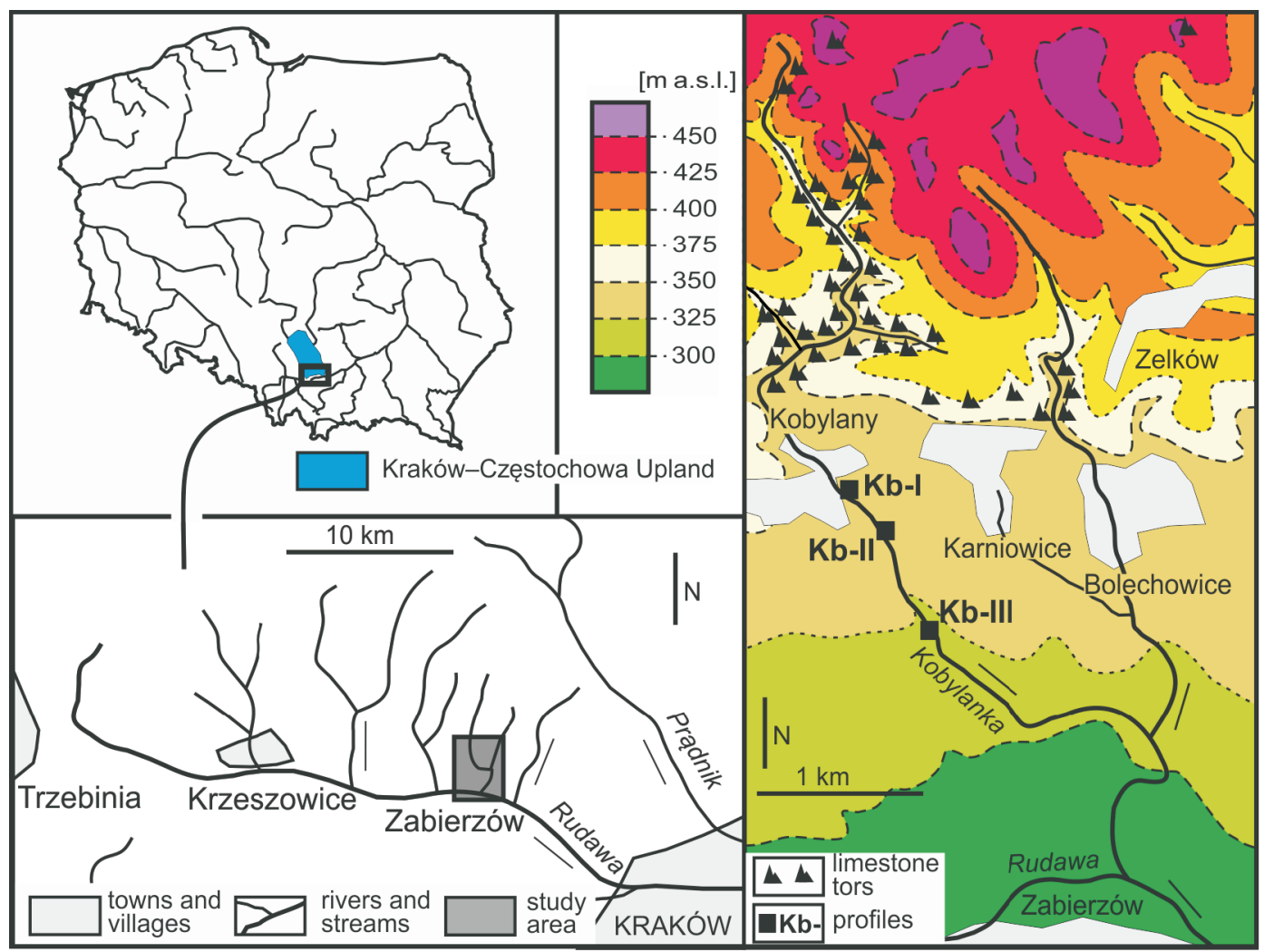

Fig. 1. Location of study area (map base: www. polska.e-mapa.net)

ment of a monocline that gently sloped towards the north-east (Rutkowski, 1989). During the Early Miocene, Outer Carpathian flysch nappes overlay the southern edge of the monocline. As a result, numerous faults were initiated, forming a system of tectonic horsts and grabens. To the west of Kraków there is an $\mathrm{E}-\mathrm{W}$ oriented graben $\sim 30 \mathrm{~km}$ long and $4 \mathrm{~km}$ wide (the Krzeszowice Graben). Its base is located at $220-310 \mathrm{~m}$ a.s.l. and it is $\sim 100 \mathrm{~m}$ lower than the Ojców Plateau that limits it to the north. Quaternary deposits also play an important role. The plain or gently hilly area of the Ojców Plateau is covered by loess formations while alluvial deposits fill the bottom of the Krzeszowice Graben. Outcrops of calcareous tufa are found in stream valleys (Walczak, 1956; Lewandowski, 2015).

The slope between the Krzeszowice Graben and the Ojców Plateau is divided by several deep valleys that are commonly rocky gorges. The Holocene successions analysed are located in the valley of the Kobylanka Stream. In its upper section this is a steep and deep valley with rocky slopes, while at its outlet into the Krzeszowice Graben there is an extensive alluvial fan where the stream cuts deeply into its own alluvium, to a depth of $5 \mathrm{~m}$. The profiles analysed represent this part of the valley (Fig. 1).

Archaeological research indicates that groups of people arrived into the area of the Kraków-Częstochowa Upland during the Lower Paleolithic. However, the Paleolithic settlements did not lead to anthropogenic transformation of the environment (e.g., Madeyska, 1982; Szymanek et al., 2016). Anthropogenic changes may be related to the arrival of Neolithic agricultural communities (e.g., Kruk et al., 1996; Kruk and Milisauskas, 1999; Moskal-del Hoyo et al., 2017, 2018; Gradziński et al., 2017). Settlement and the resulting anthropopressure were intense in areas of gentle terrain, namely on the Ojców Plateau and at the bottom of the Krzeszowice Graben. The necessity to acquire fields forced intense deforestation, resulting in decreased diversity of animal and plant species. The other consequence of deforestation was increased erosion and alluviation of mineral sediments in river valleys, mostly being a result of soil degradation (e.g., Broda, 1985; Rutkowski and Starkel, 1989; Alexandrowicz et al., 1997). By contrast, fewer traces of human activities are seen on the slope, as this was unfavourable terrain for cultivation, and so natural faunal and floral assemblages can be found in this setting until the present.

\section{MATERIAL AND METHODS}

Analysis of the mollusc assemblages was performed on 39 samples collected from three profiles (Kb-I-Kb-III; Fig. 1). Individual $2-2.5 \mathrm{~kg}$ samples were taken directly from the exposures spanning intervals of $\sim 20 \mathrm{~cm}$, depending on the lithological characteristics of the sediments. The samples represented all the lithofacies distinguished in the sections except for the hard tufas. Mollusc remains were retrieved from the samples taken, as complete shells and recognizable fragments. Identifications were made based on keys (Wiktor, 2004; Welter-Schultes, 2012; Horsák et al., 2013) and a reference collection. The shell material was subjected to standard malacological analysis (Ložek, 1964; Alexandrowicz and Alexandrowicz, 2011). Individual taxa were included into ecological groups according to the scheme described by Ložek (1964), Alexandrowicz and Alexandrowicz (2011) and Juřičková et al. (2014a; see Table 1). The percentage shares of individual ecological groups were the basis for construction of a malacological diagram. The use of principal component analysis (PCA) allowed distinction of factors crucial for fauna diversity. A similarity dendrogram analysis calculated according to the algorithm designed by Morisita (1959) allowed def- 
Malacofauna in Holocene profiles from the Kobylanka stream valley

\begin{tabular}{|c|c|c|c|c|c|c|c|}
\hline$E$ & Taxa & CL & SL & WT & OC & AA & Total \\
\hline \multirow{7}{*}{$\mathrm{F}_{\mathrm{F}}$} & Platyla polita (Hartmann, 1840) & & 56 & 6 & 1 & & 63 \\
\hline & Ruthenica filograna (Rossmässler, 1836) & & 115 & 14 & 3 & & 132 \\
\hline & Discus ruderatus (Hartmann, 1821) & 125 & 69 & 76 & & & 270 \\
\hline & Vitrea diaphana (Studer, 1820) & & 17 & & 1 & & 18 \\
\hline & Meditterranea depressa (Sterki, 1880) & 1 & 9 & 4 & & & 14 \\
\hline & Aegopinella pura (Alder, 1830) & & 168 & 28 & 11 & & 207 \\
\hline & Isognomostoma isognomostomos (Schröter, 1784) & & 38 & 4 & 6 & & 48 \\
\hline \multirow{5}{*}{$F_{B}$} & Laciniaria plicata (Draparnaud, 1801) & & 2 & 2 & 4 & & 8 \\
\hline & Balea biplicata (Montagu, 1803) & & 3 & 3 & & 5 & 11 \\
\hline & Discus rotundatus (Müller, 1774) & & 157 & 37 & 16 & & 210 \\
\hline & Aegopinella minor (Stabile, 1864) & & 8 & & & & 8 \\
\hline & Fruticicola fruticum (Müller, 1774) & 5 & 40 & & 11 & 6 & 62 \\
\hline \multirow{3}{*}{$\mathrm{F}_{\mathrm{H}}$} & Columella edentula (Draparnaud, 1805) & & & 6 & 1 & & 7 \\
\hline & Vitrea crystallina (Müller, 1774) & 12 & 197 & 54 & 34 & 10 & 307 \\
\hline & Monachoides vicinus (Rossmässler, 1842) & 27 & 128 & 73 & 44 & 28 & 300 \\
\hline \multirow{4}{*}{$\mathrm{O}_{x}$} & Truncatellina claustralis (Gredler, 1856) & & & & & 4 & 4 \\
\hline & Chondrula tridens (Müller, 1774) & & & & & 22 & 22 \\
\hline & Cecilioides acicula (Müller, 1774) & & & & & 275 & 275 \\
\hline & Meditterranea inopinata (Uličný, 1887) & & & & & 143 & 143 \\
\hline \multirow{6}{*}{$\mathrm{O}_{0}$} & Vallonia costata (Müller, 1774) & 1 & 20 & 7 & 270 & 490 & 788 \\
\hline & Vallonia pulchella (Müller, 1774) & 14 & 24 & 27 & 394 & 718 & 1177 \\
\hline & Pupilla muscorum (Linnaeus, 1758) & & & & 79 & 169 & 248 \\
\hline & Columella columella (Martens, 1830) & 131 & 11 & & & & 142 \\
\hline & Truncatellina cylindrica (Férussac, 1807) & & & & 4 & 30 & 34 \\
\hline & Vertigo pygmaea (Draparnaud, 1801) & & 1 & & 47 & 110 & 158 \\
\hline $\mathrm{M}_{\mathrm{D}}$ & Cochlicopa lubricella (Rossmässler, 1835) & & & & 15 & 106 & 121 \\
\hline \multirow{8}{*}{$M_{1}$} & Cochlicopa lubrica (Müller, 1774) & 13 & 46 & 19 & 56 & 53 & 187 \\
\hline & Punctum pygmaeum (Draparnaud, 1801) & 12 & 57 & 7 & 51 & 19 & 146 \\
\hline & Vitrea contracta (Westerlund, 1871) & & 3 & 8 & 10 & 1 & 22 \\
\hline & Euconulus fulvus (Müller, 1774) & 16 & 63 & 29 & 27 & 16 & 151 \\
\hline & Perpolita hammonis (Ström, 1765) & 14 & 107 & 49 & 109 & 23 & 302 \\
\hline & Vitrina pellucida (Müller, 1774) & 1 & 11 & 5 & 31 & 18 & 66 \\
\hline & Limacidae & 5 & 21 & 5 & 25 & 22 & 78 \\
\hline & Trochulus hispidus (Linnaeus, 1758) & & 5 & 4 & 1 & & 10 \\
\hline \multirow{5}{*}{$\mathrm{M}_{\mathrm{H}}$} & Carychium tridentatum (Risso, 1826) & & 81 & 29 & 71 & 41 & 222 \\
\hline & Succinella oblonga (Draparnaud, 1801) & 16 & 35 & 17 & 49 & 17 & 134 \\
\hline & Vertigo substriata (Jeffreys, 1833) & 106 & 75 & 33 & & & 214 \\
\hline & Vertigo angustior Jeffreys, 1830 & & 16 & 6 & 13 & 2 & 37 \\
\hline & Perforatella bidentata (Gmelin, 1791) & 19 & 183 & 82 & 53 & 27 & 364 \\
\hline \multirow{6}{*}{$\mathrm{H}$} & Carychium minimum Müller, 1774 & 22 & 111 & 92 & 95 & 29 & 349 \\
\hline & Succinea putris (Linnaeus, 1758) & 18 & 81 & 72 & 51 & 32 & 254 \\
\hline & Vertigo antivertigo (Draparnaud, 1801) & & 18 & 28 & 24 & 7 & 77 \\
\hline & Vertigo genesii (Gredler, 1856) & 142 & 19 & & & & 161 \\
\hline & Vertigo geyeri Lindholm, 1925 & 118 & 11 & & & & 129 \\
\hline & Zonitoides nitidus (Müller, 1774) & 2 & 60 & 14 & 27 & 14 & 117 \\
\hline \multirow{4}{*}{$W_{T}$} & Valvata cristata (Müller, 1774) & 5 & 43 & 66 & 41 & 17 & 172 \\
\hline & Galba truncatula (Müller, 1774) & 71 & 71 & 201 & 127 & 35 & 505 \\
\hline & Anisus leucostoma (Millet, 1813) & 48 & 81 & 265 & 169 & 48 & 611 \\
\hline & Pisidium obtusale (Lamarck, 1818) & 14 & 57 & 104 & 37 & 6 & 218 \\
\hline \multirow{7}{*}{$W_{S}$} & Gyraulus laevis (Alder, 1838) & 70 & 22 & 38 & & & 130 \\
\hline & Bithynia tentaculata (Linnaeus, 1758) & & 5 & 14 & 12 & 1 & 32 \\
\hline & Radix peregra (Müller, 1774) & 11 & 8 & 33 & 4 & 16 & 72 \\
\hline & Gyraulus crista (Linnaeus, 1758) & 10 & 53 & 87 & 43 & 26 & 219 \\
\hline & Pisidium milium Held, 1836 & 16 & 14 & 62 & 1 & & 93 \\
\hline & Pisidium casertanum (Poli, 1791) & 6 & 23 & 110 & 43 & 4 & 186 \\
\hline & Pisidium subtruncatum Malm, 1855 & 13 & 4 & 77 & 19 & 4 & 107 \\
\hline \multirow{2}{*}{$W_{R}$} & Pisidium amnicum (Müller, 1774) & & 4 & & 5 & 2 & 11 \\
\hline & Pisidium personatum Malm, 1855 & 8 & 9 & 120 & 16 & 21 & 174 \\
\hline \multicolumn{2}{|c|}{ Total species } & 33 & 50 & 43 & 45 & 40 & 58 \\
\hline & Total individuals & 1092 & 2460 & 2017 & 2151 & 2617 & 10471 \\
\hline
\end{tabular}

E - ecological groups of molluscs (after Ložek, 1964; Alexandrowicz and Alexandrowicz, 2011; Juřičková et al., 2014a): $F_{F}$ - shadow-loving, forest species, $F_{B}$ - shadow-loving species living in light forests and bushy zones, $\mathrm{F}_{\mathrm{H}}$ - shadow-loving species of humid habitats, $\mathrm{O}_{\mathrm{X}}$ - xerophilous and underground species, $\mathrm{O}_{\mathrm{O}}-$ open-country species, $M_{D}$ - mesophilous species of dry habitats, $M_{1}-$ mesophilous species of moderately wet habitats, $\mathrm{M}_{\mathrm{H}}$ - mesophilous species of wet habitats, $\mathrm{H}$ - hygrophilous species, $\mathrm{W}_{\mathrm{T}}$ - species of temporary water bodies, $W_{S}$ - species of permanent water bodies, $W_{R}$ - reophile species; mollusc assemblages $(C L, S L, W T$, OC, AA; described in text) 


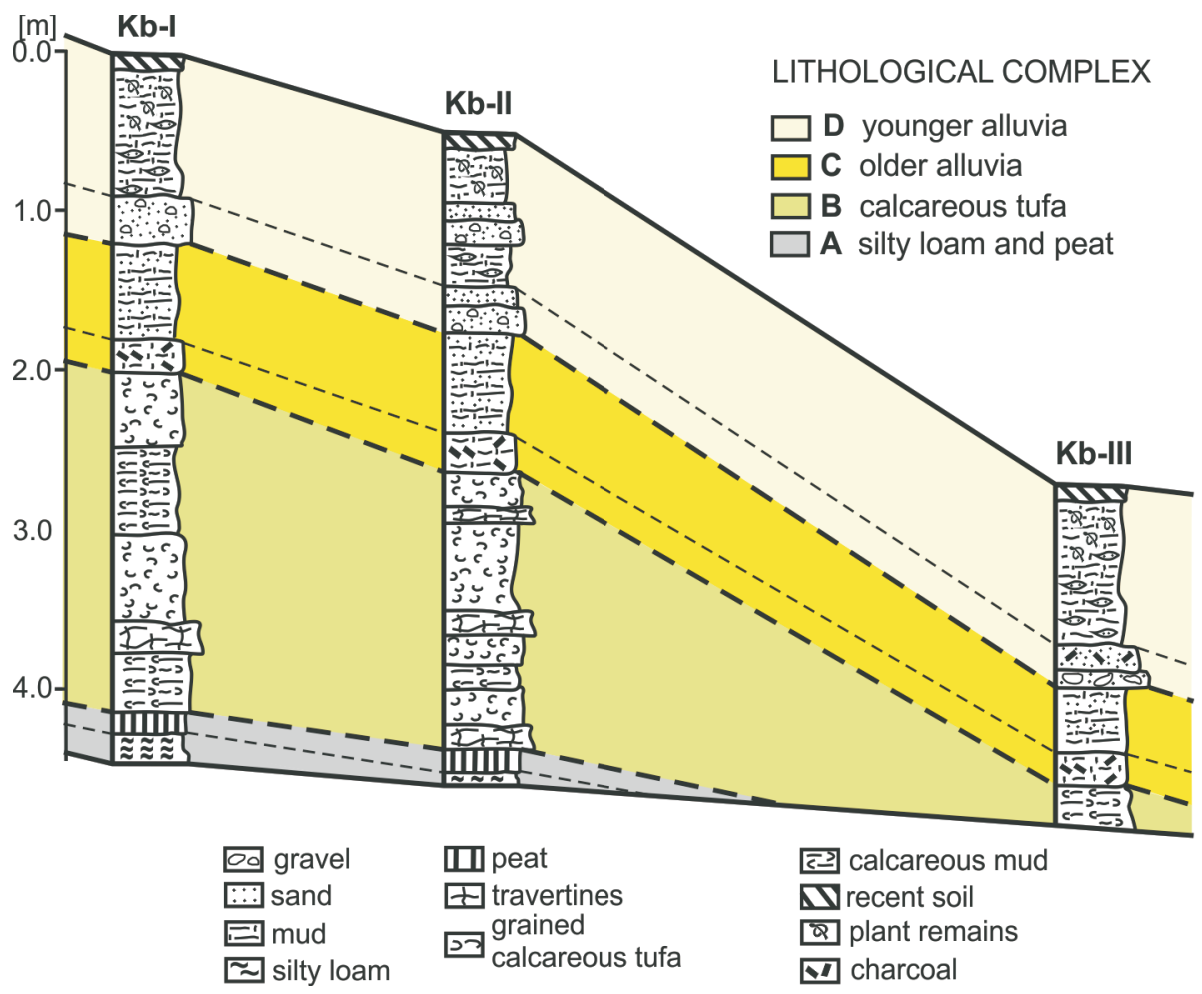

Fig. 2. Lithology of Holocene deposits in the Kobylanka Stream Valley

$\mathrm{Kb}-\mathrm{I}-\mathrm{Kb}-\mathrm{III}$ profiles analysed

inition of mollusc assemblages. Statistical calculations were made using PAST software (Hammer et al., 2001). The data thus collected were the basis for reconstructing environmental changes, both those resulting from natural factors and those directly related to human activity. The paper uses the formal division of the Holocene adopted by the IUGS in 2018 (Walker et al., 2019). The stratigraphic position of individual assemblages was determined on the basis of age determination for 8 samples of plant remains and charcoal using the radiocarbon method. The radiometric analyses were made in the laboratory in Gliwice (code Gd), the ages obtained being calibrated using OxCal V 3.9 software (Bronk Ramsey, 2003). The palaeoenvironmental reconstructions were compared with the results of malacological studies carried out at other Holocene sites in the southern part of Kraków-Częstochowa Upland (e.g., Alexandrowicz, 1983, 1997, 2004; Alexandrowicz et al., 1997).

\section{RESULTS}

\section{LITHOLOGY}

The analysis encompassed three exposures located within the alluvial fan of the Kobylanka Stream. Profiles Kb-I and Kb-II are located in the proximal fan and expose a sedimentary sequence $\sim 4 \mathrm{~m}$ thick. Profile $\mathrm{Kb}-\mathrm{III}$ is located in the distal fan and its thickness is $2 \mathrm{~m}$ (Figs. 1 and 2). Within the profiles four lithological units (A-D) may be distinguished.

Unit $A$, the oldest part of the sequence, is characterized by dark silty loams and a $25 \mathrm{~cm}$ thick layer of black peat. These deposits are exposed at the base of the $\mathrm{Kb}-\mathrm{I}$ and $\mathrm{Kb}-\mathrm{Il}$ profiles (Fig. 2).
Unit B comprises calcareous deposits developed as hard, porous white travertine and white or yellowish granular tufa, and white calcareous silt. These carbonate deposits are thickest in profile Kb-I (slightly $>2 \mathrm{~m}$ ). Closer to the valley bottom, the thickness of the calcareous tufa decreases to $\sim 1.8 \mathrm{~m}$ in the $\mathrm{Kb}-\mathrm{II}$ profile and $<0.5 \mathrm{~m}$ in the Kb-III profile (Fig. 2).

The next unit $(\mathrm{C})$ consists of two types of deposit. The first is a $0.3 \mathrm{~m}$ thick layer of dark silt with fragments of charcoal. The second type is silt with fine-grained sand, usually up to $0.8 \mathrm{~m}$ thick. Similar to many fluvial deposits in the vicinity of Kraków, unit C is an example of the "older agricultural alluvial soil" (Rutkowski and Starkel, 1989; Alexandrowicz et al., 1997; Fig. 2).

The upper sections in all profiles (unit D) comprise a mineral fluvial deposit typical of the vicinity of Kraków and known as the younger agricultural alluvial soil (Rutkowski and Starkel, 1989; Alexandrowicz et al., 1997). It includes gravel and sand overlain by silt with plant remains (Fig. 2), with a high content of calcium carbonate. Thus, they provide convenient conditions to protect subfossil molluscs assemblages.

\section{MALACOFAUNA}

The malacological analysis was based on 39 samples. The number of species in individual samples ranged from 12 to 40 , while the number of specimens ranged from 103 to 780 . The material in total consisted of over 10,000 specimens belonging to 45 species of terrestrial snail, 8 species of aquatic snail and 5 species of bivalve (Table 1).

Shade-loving species (groups $F_{F}, F_{B}, F_{H}$ ) are a dominant element in lower parts of the profiles (units $A$ and $B$; Figs. 2, 3 and Table 1). In unit $A$ and the lower part of unit $B$ moisture-tolerant taxa of wide thermal tolerance are present: Discus ruderatus 

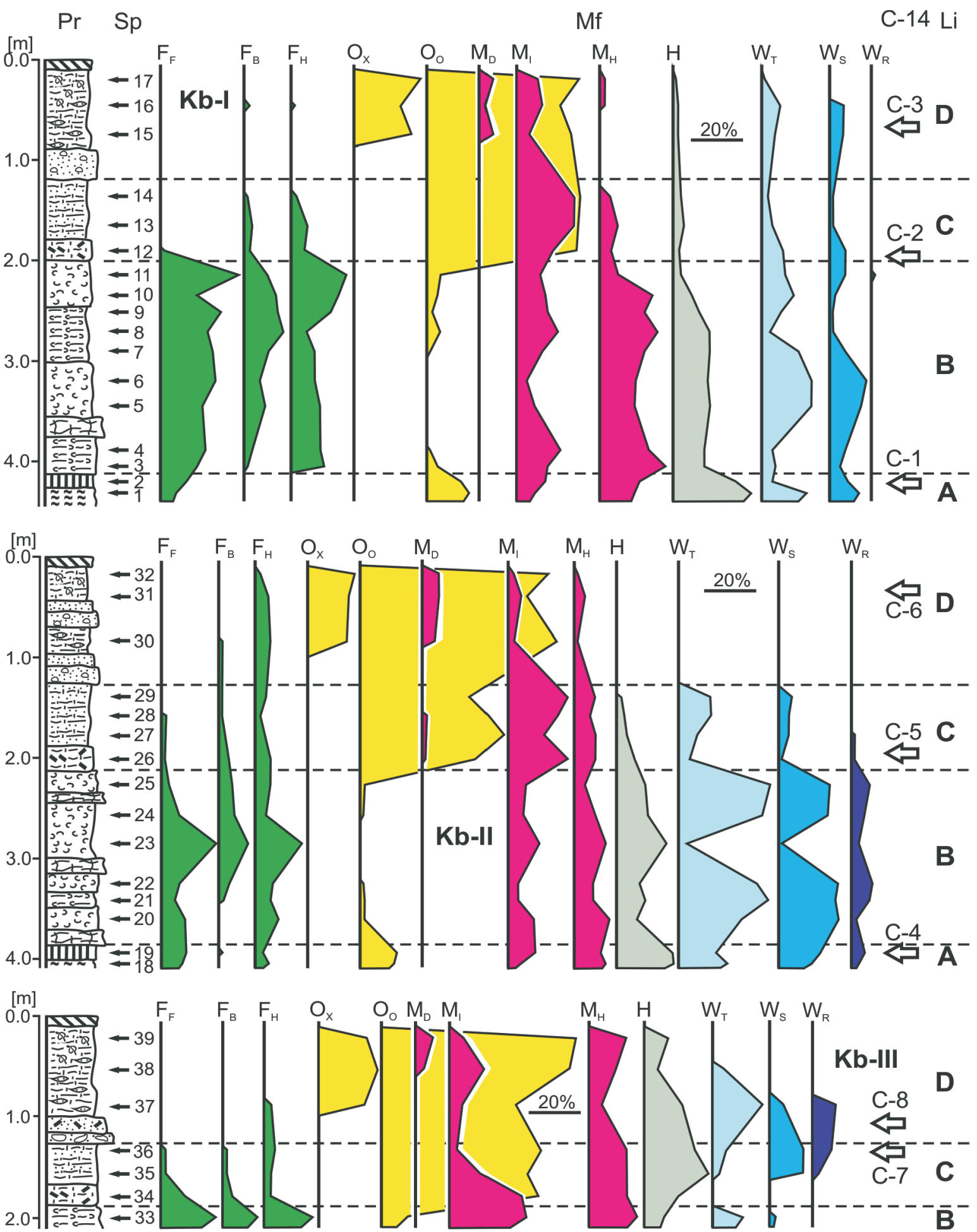

四 14-C datings $\square$ samples with fauna

Fig. 3. Lithology and malacological diagrams of the Kobylanka Valley profiles

$\mathrm{Pr}$ - profile, $\mathrm{Sp}$ - samples, Mf - malacofauna; $F_{F}, F_{B}, F_{H}, O_{X}, O_{O}, M_{D}, M_{1}, M_{H}, H, W_{T}, W_{S}, W_{R}$ - ecological groups of molluscs - for explanations see Table 1; Li - lithological units (A-D; described in text); for lithological explanations see Figure 2 


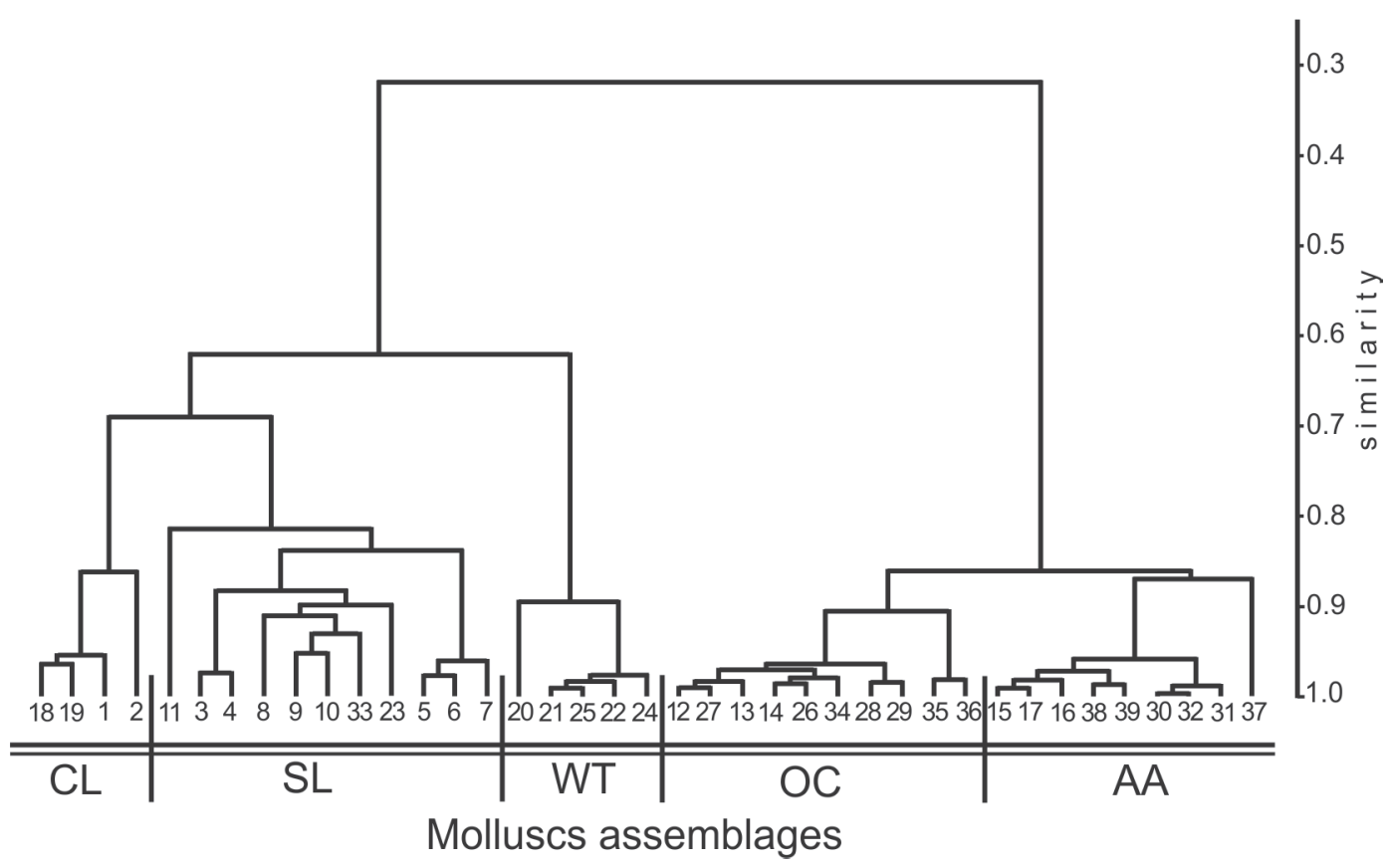

Fig. 4. Cluster analysis of mollusc assemblages from the Holocene deposits of the Kobylanka Valley

1-36 - samples, CL, SL, WT, OC, AA - mollusc assemblages described in text

and Vitrea crystallina. In the higher part of unit B forest species are much more numerous and constitute $\sim 50 \%$ of the assemblage. Species diversity also increases, with the occurrence of various taxa with stricter ecological requirements: Aegopinella pura, Ruthenica filograna and Discus rotundatus. Within units C and $D$ forest species play a marginal role (Fig. 3 and Table 1). In the higher part of the sequence (units $C$ and $D$ ) open-country species (groups $\mathrm{O}_{\mathrm{x}}, \mathrm{O}_{\mathrm{O}}$ ) are dominant, particularly taxa living in moderately dry, grassy habitats: Vallonia pulchella and Vallonia costata (Table 1). In the uppermost part (unit D) there are two soil-dwelling species: Cecilioides acicula and Meditterranea inopinata (Fig. 3 and Table 1). In the lower part of the sequence the presence of Columella columella is significant. Mesophilous species (groups $M_{D}, M_{1}, M_{H}$ ) occur throughout the sequence, but they are more common in its lower part (Fig. 3 and Table 1), notably Vertigo substriata. Hygrophilous species (group $\mathrm{H}$ ) are relatively rare, though of great importance in interpretation, especially Vertigo genesii and $V$. geyeri. The molluscs identified in the profiles include aquatic species, notably those living in temporary water bodies (group $\mathrm{W}_{\mathrm{T}}$; Galba truncatula and Anisus leucostoma). Less common are taxa typical of permanent small and shallow, vegetated water bodies (group $W_{S}$ ), notably Gyraulus laevis. Two species of bivalves characteristic of flowing water (group $W_{R}$ ) are the final element of the assemblage (Fig. 3 and Table 1).

\section{DISCUSSION}

\section{MOLLUSCS ASSEMBLAGES}

The mollusc assemblages identified in the profiles analysed are highly variable. This variability is both in species diversity and in the ecological structure of the assemblages present in different intervals of the sequence. Taxonomic analysis, based on a dendrogram of similarities, allows distinction of two clearly separate groups. The first group includes samples obtained from the lower parts of the profiles, belonging to lithological units $A$ and $B$ (samples $1-11,18-25$ and 33 ). The remaining samples (samples 12-17, 26-32, 34-39) fall within the second group and correspond with the lithological units $A$ and $B$ (Figs. 2-4). In more detailed analysis, five molluscs assemblages were recognized, differing in taxonomical composition and habitat and temperature preferences (Fig. 4), the age of individual molluscs assemblages being determined by radiocarbon dating of plant remains and charcoal fragments, that generally give reliable and relatively low-error results (Fig. 3 and Table 2).

The assemblage with cold-loving species (CL). This relatively poor fauna (33 species; Table 1) is present in the lowest sections of the $\mathrm{Kb}-\mathrm{I}$ and $\mathrm{Kb}$-II profiles within lithological unit $\mathrm{A}$ (Figs. 2-4). The most important environmental factor for this assemblage is the presence of wetland habitats (Fig. 5), with characteristic taxa that prefer a cold climate: Vertigo genesii, V. geyeri and Columella columella. These are common in assemblages related to the Late Glacial and Early Holocene, as seen in many profiles across Europe (e.g., Alexandrowicz, 1983, 1997, 2004, 2013a, 2015, 2019a, b; Limondin-Lozouet, 1992; Krolopp and Sümegi, 1993; Meyrick, 2001, 2002; Meyrick and Preece, 2001; Gedda, 2001, 2006; Alexandrowicz et al., 2014, 2016; Juřičková et al., 2014b; Horáčková et al., 2015). They are rare in younger deposits and nowadays in Central Europe are known only from a few relict sites (Schenková and Horsák, 2013) or in high mountains (Pokryszko, 1990; Fig. 3 and Table 1). The presence of the moisture- and shade-loving forms Discus ruderatus and Vertigo substriata is also important, both being moisture-tolerant species common in assemblages related to the Early Holocene (e.g., Alexandrowicz, 1983, 1997, 2004, 2013a; Gedda, 2001, 2006; Meyrick, 2001, 2002; Meyrick and Precce, 2001; Alexandrowicz et al., 2014, 2016; Juřičková et al., 2014b; Horáčková et al., 2015). There were also many Gyraulus laevis, a cold-tolerant taxon typical of small overgrown water bodies (Alexandrowicz, 1999, 2013b). The CL assemblage is characterized by wetland habitats with patches 
Table 2

Results of radiocarbon dating

\begin{tabular}{|c|c|c|c|c|c|c|}
\hline Profile & Sample & Age BP & Lab code & Age cal BP & Age cal BC/AD & Material \\
\hline $\mathrm{Kb}-\mathrm{I}$ & $\mathrm{C}-1$ & $9870 \pm 100$ & Gd-2941 & $\begin{array}{c}11750-11731(0.6 \%) \\
11725-11103(94.8 \%)\end{array}$ & $\begin{array}{c}9801-9782(0.6 \%) \mathrm{BC} \\
9776-9154(94.8 \%) \mathrm{BC}\end{array}$ & peat \\
\hline $\mathrm{Kb}-\mathrm{I}$ & $\mathrm{C}-2$ & $3300 \pm 100$ & Gd-2584 & $\begin{array}{c}3828-3786(2.7 \%) \\
3780-3344(92.5 \%) \\
3281-3278(0.2 \%)\end{array}$ & $\begin{array}{c}1879-1837(2.7 \%) \mathrm{BC} \\
1831-1395(92.5 \%) \mathrm{BC} \\
1332-1329(0.2 \%) \mathrm{BC}\end{array}$ & charcoal \\
\hline $\mathrm{Kb}-\mathrm{I}$ & $\mathrm{C}-3$ & $730 \pm 50$ & Gd-9266 & $\begin{array}{c}758-753(0.4 \%) \\
745-632(83.4 \%) \\
599-560(11.6 \%) \\
\end{array}$ & $\begin{array}{c}1193-1197(0.4 \%) \text { AD } \\
1205-1319(83.4 \%) \text { AD } \\
1352-1390(11.6 \%) \text { AD }\end{array}$ & plant remains \\
\hline $\mathrm{Kb}-\mathrm{II}$ & $\mathrm{C}-4$ & $9300 \pm 80$ & Gd-7330 & 10688-10264 (95.4\%) & $8739-8315(95.4 \%) \mathrm{BC}$ & peat \\
\hline $\mathrm{Kb}-\mathrm{II}$ & $C-5$ & $3700 \pm 50$ & Gd-10888 & $\begin{array}{c}4224-4205(1.6 \%) \\
4158-3894(93.8 \%)\end{array}$ & $\begin{array}{c}2275-2256(1.6 \%) \mathrm{BC} \\
2209-1945(93.8 \%) \mathrm{BC}\end{array}$ & charcoal \\
\hline $\mathrm{Kb}-\mathrm{II}$ & $\mathrm{C}-6$ & $370 \pm 50$ & Gd-2434 & $5405-313(95.4 \%)$ & 1445-1637 (95.4\%) AD & plant remains \\
\hline $\mathrm{Kb}-\mathrm{III}$ & C-7 & $2650 \pm 50$ & Gd-11201 & $2865-2718(95.4 \%)$ & 916-769 (95.4\%) BC & charcoal \\
\hline $\mathrm{Kb}-\mathrm{III}$ & $\mathrm{C}-8$ & $820 \pm 60$ & Gd-9533 & $\begin{array}{l}906-851(11.1 \%) \\
832-667(84.3 \%)\end{array}$ & $\begin{array}{l}1044-1100(11.1 \%) \text { AD } \\
1119-1283(84.3 \%) A D\end{array}$ & plant remains \\
\hline
\end{tabular}

of coniferous forest, growing in a cold, apparently continentally influenced, climate. This fauna represents the Early Holocene (for dates of $\mathrm{C}-1$ and $\mathrm{C}-4$ see Fig. 3 and Table 2). Similar molluscs communities of this age have been described from many sites in Europe (e.g., Alexandrowicz, 1983, 1997, 2004, 2013a, 2015, 2019a; Limondin-Lozouet, 1992; Meyrick, 2001, 2002; Meyrick and Preece, 2001; Gedda, 2001, 2006; Alexandrowicz et al., 2014, 2016; Juřičková et al., 2014b; Horáčková et al., 2015).

The assemblage with aquatic species (WT). This assemblage is particularly well developed within the calcareous tufas (unit B; Figs. 2-4). The most important environmental factor for this assemblage is the presence of small temporary or permanent water bodies (Fig. 5). This fauna consists of 43 taxa (Table 1). Its characteristic feature is the presence of aquatic species living both in temporary water bodies (Galba truncatula and Anisus leucostoma) and in small and shallow permanent water bodies with rich plant vegetation. Granular calcareous tura and/or calcareous silt are associated with this type of environment (e.g., Pedley, 1990, 2009). Land snails preferring wet habitats (Perforatella bidentata and Carychium minimum) were also noted. This fauna inhabited small temporary water bodies developing on the waterlogged bottom of the valley overgrown by bushes with common alder and willow. Similar assemblages have been described from other sites with Holocene calcareous tufa (e.g., Keen, 1990; Alexandrowicz, 2004, 2012; Dobrowolski et al., 2016, 2019).

The assemblage with shade-loving species (SL). This abundant and diverse fauna (50 species; Table 1) is present in all profiles within the calcareous tufas (unit B; Figs. 2-4). The main factor for this fauna is the presence of forest (Fig. 5). The assemblage contains numerous shells of forest species with strict ecological requirements, especially in terms of temperature: Discuis rotundatus, Aegopinella pura and Ruthenica filograna, accompanied by shade-tolerant snails preferring moist habitats (Monachoides vicinus and Vitrea crystallina) and mesophilous taxa. The importance of other ecological groups is lesser. This assemblage is characterized by shaded and moist habitats located at the bottom of the valley, associated with mixed or deciduous dense forests. Significant species diversity, many thermophilic forest taxa, the lack of species with low thermal requirements and few open environment snails is typical of assemblages related to the Middle Holocene. Similar mollusc assemblages have been identified at many sites in entire Cen- tral and Western Europe (e.g., Alexandrowicz, 1997, 2004, 2015, 2019a, b; Meyrick, 2002; Žak et al., 2002; Alexandrowicz and Rybska, 2013; Alexandrowicz et al., 2014, 2016; Juřičková et al., 2014b; Horáčková et al., 2015).

The assemblage with open-country species (OC). This fauna is present in all profiles within lithological unit $C$ (Figs. 2-4). The most important environmental factor is the presence of moderately dry open, grassy habitats (Fig. 5). It is characterized by significant species diversity (45 species; Table 1). The two most important taxa characteristic of grasslands are Vallonia pulchella and Vallonia costata that constitute $>30 \%$ of the assemblage. The assemblage also includes mesophilous snails, especially those preferring dry and moderately moist habitats. Shade-tolerant snails constitute $<5 \%$ of the assemblage. This fauna is typical of dry grassy habitats. The deposits containing the $\mathrm{OC}$ assemblage formed during earlier part of the Late Holocene (for radiocarbon dates of C-5 and C-7 see Fig. 3 and Table 2). Similar assemblages have been described also in other Late Holocene mollusc-bearing sequences in Europe (e.g., Alexandrowicz et al., 1997, 2014, 2016, 2019; Alexandrowicz, 2013c, 2020; Granai and Limondin-Lozouet, 2018; Horsák et al., 2019; Davišek et al., 2020).

The assemblage with species typical of agricultural areas (AA). This fauna is present in the uppermost sections of all profiles, within lithological unit D (Figs. 2-4). It is characterized by relatively high species diversity (40 taxa, Table 1). The most important environmental factor is arable land (Fig. 5). Open-country species are the dominant component of this fauna (up to $75 \%$ ). Snails typical of open grassy biotopes are numerous (Vallonia pulchella and Vallonia costata), while the most important group comprises underground forms living in the soil (Cecilioides acicula and Meditterranea inopinata). Both these snails are commonly found in agricultural areas, especially on arable land. Their occurrence with anthropogenically modified areas has been documented at many sites (e.g., Rousseau et al., 1993; Alexandrowicz et al., 1997, 2019; Alexandrowicz, 2004; Groom, 2011; Čiliak et al., 2015). Shade-loving taxa are absent and the presence of other ecological groups is low. The assemblage with species typical of agricultural areas represents the youngest sediments, deposited during the last millennium (radiocarbon dating: C-3, C-6 and C-8; see Fig. 3 and Table 2). 


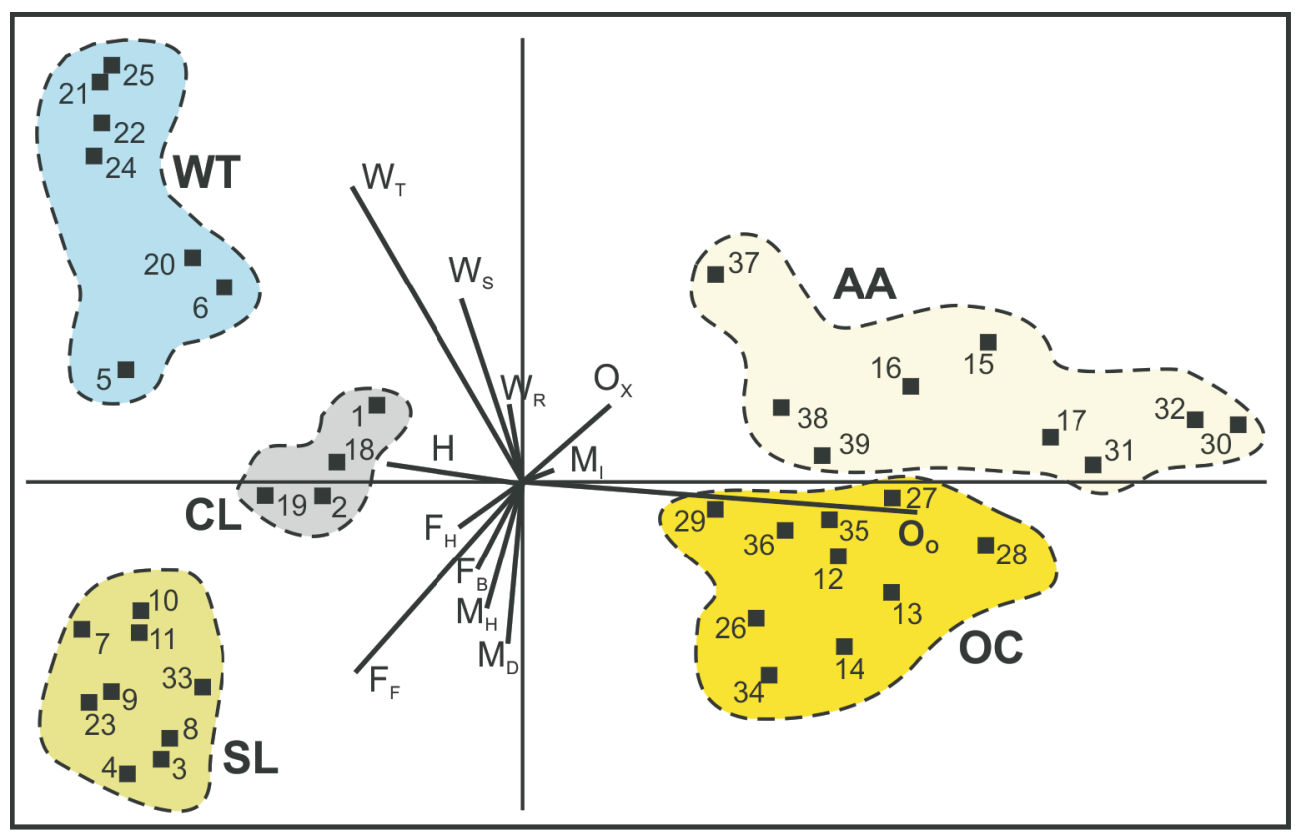

Fig. 5. Principal component analysis (PCA) of malacofauna from the Kobylanka Stream Valley

$F_{F}, F_{B}, F_{H}, O_{X}, O_{O}, M_{D}, M_{l}, M_{H}, H, W_{T}, W_{S}, W_{R}$ - ecological groups of molluscs - for explanations see Table 1, 1-36 - samples, CL, SL, WT, OC, AA - mollusc assemblages described in the text

\section{NATURAL AND ANTHROPOGENIC ENVIRONMENTAL CHANGES}

Profiles from the Kobylanka Stream Valley contain a malacological succession representing the entire Holocene. The composition and structure of the molluscs assemblages reflect environmental conditions present at the time and location of sedimentation. Thus, they allow reconstruction of palaeoenvironmental evolution, and indicate the main factors determining changes, and the time intervals during which these changes occurred. Six such phases can be distinguished.

Phase I (Early Holocene). This phase relates to the earliest-deposited unit A (for dates of C-1 and C-4, see Table 2). The malacofauna includes many shells of cold-tolerant taxa (assemblage CL) that lived in moist, shaded habitats (Fig. 5). During the Early Holocene, forests spread into Central Europe (e.g., Giesecke et al., 2017; Roberts et al., 2018). This regional trend of environmental change has been documented at many other sites, both in southern Poland (e.g., Alexandrowicz, 1983, 1997, 2004, 2013a, 2015, 2019a; Alexandrowicz et al., 2014, 2016) and across Central and Western Europe (e.g., Limondin-Lozouet, 1992; Krolopp and Sümegi, 1993; Meyrick, 2001, 2002; Meyrick and Preece, 2001; Gedda, 2001, 2006; Žak et al., 2002; Horsák et al., 2019). The evidence indicates a gradually increase of forest habitats, reflected by the growing presence and increasing species diversity of shade-loving taxa (Fig. 5), indicating progressive warming of the climate. The data collected indicate that during the Early Holocene the Kobylanka Stream flowed through a relatively broad valley. Its bottom was swampy with temporary water bodies, overgrown by grass with clumps of bushes, mostly alder and willow. Coniferous forests covered the slopes of the valley (Fig. 6). No human impact on natural environmental processes during this period was identified. During the Early Holocene some small hunter-gatherer communities were continuously or periodically living in the vicinity of Kraków, making limited use of environmental resources from this area (Madeyska, 1982; Szymanek et al., 2016).
Phase II (Middle Holocene). This was a period of warm and humid climate in which calcareous tufas were deposited. The middle sections of the $\mathrm{Kb}-\mathrm{I}$ and $\mathrm{Kb}-\mathrm{II}$ profiles and the lower part of profile $\mathrm{Kb}-\mathrm{III}$ are built of various types of calcareous tufa (unit B). Two types of mollusc assemblage are present in these deposits. The first one includes shade-loving species and the second contains aquatic molluscs (Fig. 5). Both these faunal types indicate gradual climate warming, as well as increasing humidity and continued change in the dominant climatic circulation from continental to oceanic. These observations are consistent with climatic change models for the area of Central Europe during the Holocene (Mayewski et al., 2004; Mauri et al., 2015). The co-existence of two different mollusc assemblages indicates heterogeneous conditions at the valley bottom. Around profile $\mathrm{Kb}-\mathrm{I}$ there were dense deciduous forests while near the Kb-II profile there was a shallow, highly overgrown, probably temporary water body. Several such former water bodies have been identified in valleys on the southern edge of the Kraków-Częstochowa Upland (Alexandrowicz, 1983, 1997, 2004, 2012). These small lakes were often confined by dams built of hard travertine and filled with loose calcareous tufa. They were probably created as a result of the valley being blocked by fallen trees, following mass wasting or through the activity of beavers (Alexandrowicz, 2004, 2012; Fig. 6). The molluscan diversity indicates the existence of varied microhabitats. Thus, the bottom of the Kobylanka Stream Valley was locally overgrown with forests or bushes, while locally open habitats with small temporary water bodies existed (Fig. 6). Such mid-Holocene assemblages with large numbers of thermophilic taxa are known from many sites across Europe (e.g., Alexandrowicz, 1997, 2004, 2015, 2019a, b; Meyrick, 2002; Žak et al., 2002; Alexandrowicz and Rybska, 2013; Alexandrowicz et al., 2014, 2016; Juřičková et al., 2014b; Horáčková et al., 2015). During this period human settlement occurred mostly on the hilltop plain of the Upland. Then, the first anthropogenic deforestations took place (e.g., Kruk et al., 1996; Kruk and Milisauskas, 1999; Moskal-del Hoyo et al., 2017, 


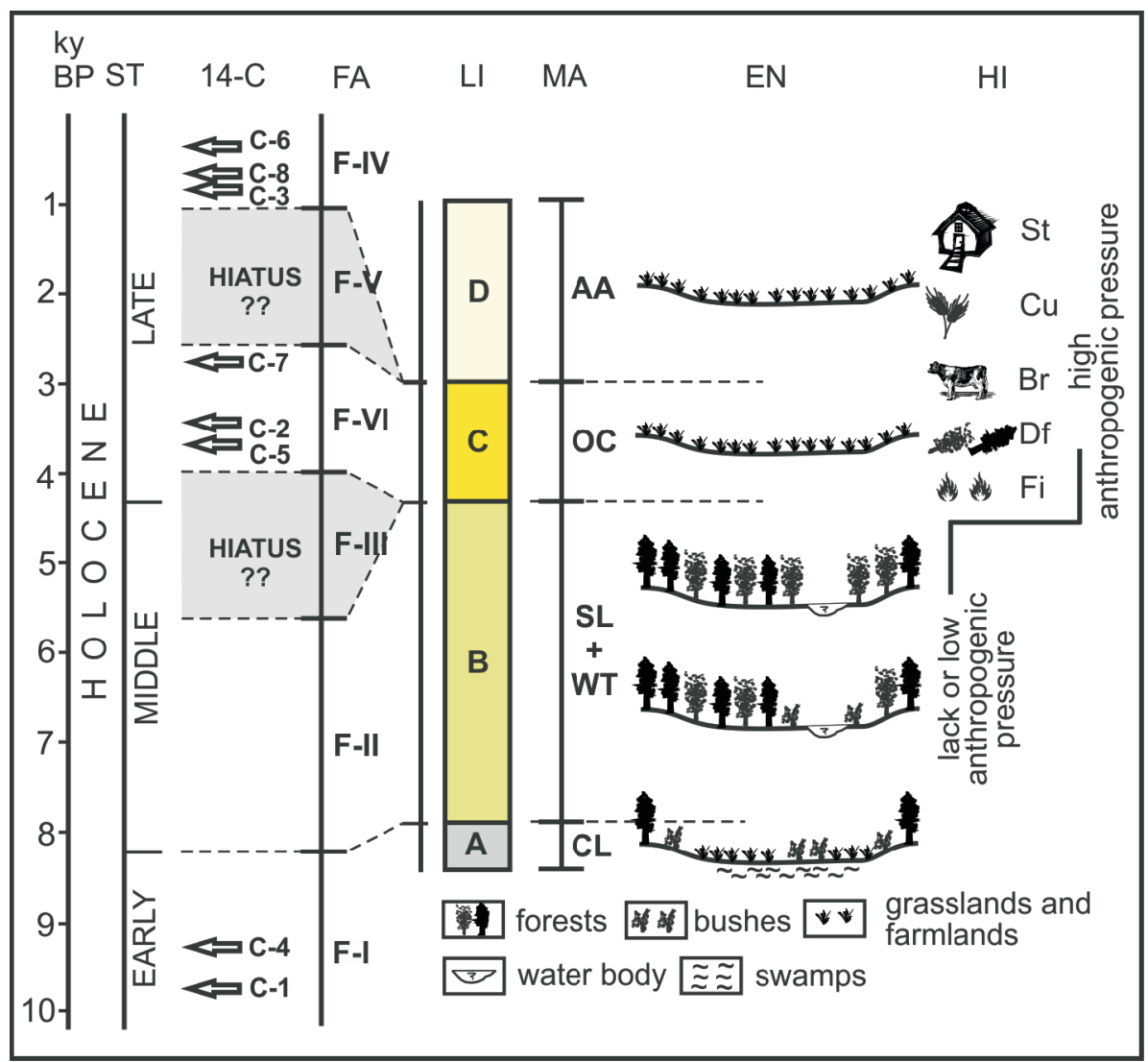

Fig. 6. Natural and anthropogenic environmental changes in the Kobylanka stream valley during the Holocene

ST - Stratigraphy (after Walker et al., 2019), 14-C - radiocarbon dating (see Table 2), FA phases of environmental change (F-I-F-VI; described in text), LI - lithological units (A-D; described in text, see Fig. 2), MA - mollusc assemblages (CL, SL, WT, OC, AA; described in text), $\mathrm{EN}$ - environmental changes, $\mathrm{HI}$ - human impact: $\mathrm{Fi}$ - fire, $\mathrm{Df}$ - deforestation, $\mathrm{Br}$ - breeding, $\mathrm{Cu}$ - cultivation, St - settlement

2018), though this research has identified no human impact on geological processes for the period discussed.

Phase III (Middle Holocene/Late Holocene). This was a time of climatic changes occurring across Central Europe (Mayewski et al., 2004; Mauri et al., 2015), with limited deposition of carbonate sediments, as described from numerous sites in Europe (e.g., Goudie et al., 1993; Dobrowolski et al., 2012, 2016, 2019; Väliranta et al., 2016; Dabkowski, 2020) as well as in the Kobylanka Valley. This is commonly related to a stratigraphic hiatus up to several hundred years in duration (Jäger and Ložek, 1983; Alexandrowicz, 2004; Fig. 6).

Phase IV (Late Holocene - older part). Fluvial deposits related to this period are present in all profiles (unit C). The time of deposition is constrained by radiocarbon dating of the $\mathrm{Kb}-\mathrm{I}$ and $\mathrm{Kb}-\mathrm{Il}$ profiles (C-2, C-5 and C-7; Table 2). Calcareous tufa was replaced by sandy and silty mineral sediments. At the base of these deposits there is a characteristic layer containing significant charcoal debris. This is the 'older agricultural alluvial soil' (Rutkowski and Starkel, 1989; Alexandrowicz et al., 1997). The earlier plentiful and diverse assemblages with many shade-loving snails were replaced by assemblages dominated by open-country species (Fig. 5). The rapid deforestation recorded in the profiles (Fig. 6) is undoubtedly a result of anthropogenic deforestation occurring during growth of Neolithic agricultural areas around Kraków (e.g., Kruk et al., 1996; Kruk and Milisauskas, 1999; Moskal-del Hoyo et al., 2017, 2018;
Gradziński et al., 2017). The charcoal is evidence of forest burning in the Kobylanka drainage basin. Clear evidence of anthropogenic burning and deforestation of large areas of the Kraków-Częstochowa Upland during this period have been identified at many sites (Alexandrowicz, 1983, 1997, 2004; Broda, 1985; Rutkowski and Starkel, 1989). As a result of these processes, natural forests disappeared and were replaced by open grassy biotopes used as pastures (Fig. 6).

Phase V (Late Holocene - younger part). This was a period of rapid, brief climate changes (Mayewski et al., 2004; Mauri et al., 2015). It can be seen in all the profiles in the Kobylanka Valley as a thick layer of gravel and sand. These deposits may represent a period of intensified fluvial activity preceding the Early Medieval phase of settlement, and so may correspond to cool climatic phases of the Iron Age or Dark Ages (Starkel, 1997; Starkel et al., 2013; Fig. 6).

Phase $\mathrm{VI}$ (the last millennium). This was a period of intense human settlement and activity. In the Kobylanka Valley profiles it can be seen in the top interval (unit D). This has been entirely created during the last millennium (for radiocarbon dates of C-3, C-6 and C-8; Table 2). The malacofauna reveals a domination of open and dry habitats (Fig. 5). Increasing population density and the spread of arable land and villages led to complete deforestation of the valley (Fig. 6). Species typical of arable land and related to agricultural development were also present. Historical data show that the most rapid human settlement 
took place in this area since the 11th/12th century, with intensified anthropogenic pressure since (Fig. 6). Mineral sediments containing plant remains, commonly found in the top part of all profiles, are known as the younger agricultural alluvial soil (Rutkowski and Starkel, 1989; Alexandrowicz et al., 1997).

\section{CONCLUSIONS}

The profiles exposed in the Kobylanka Valley allow reconstruction of environmental changes and evaluation of human impact on environmental processes during the Holocene. All profiles analysed can be divided into two parts. Their lower sections were formed during the Early and Middle Holocene, when the valley of the stream of Kobylanka was not subject to human activity. As a result, only natural processes controlled environmental changes, climate being the most important factor. The faunal sequence indicates progressive warming accompanied by a gradual change in dominant atmospheric circulation from continental to oceanic. As a result, original cold-loving tundra plant assemblages were replaced by forest, primarily coniferous and then with growing numbers of warmer-climate trees. This vegetation change was accompanied by a change in molluscs assemblages, as cold-tolerant forms disappeared, while species with high environmental requirements, especially forest species, started to occur. Within the upper parts of the profiles the most important factor determining environmental evolution was human activity. Its first and the most visible sign was deforestation taking place since the beginning of the Late Holocene. The older alluvial soil formed in that period contains significant amounts of charcoal as evidence of burning and clearing of large forest areas. The open grassy habitats so formed were probably used as pastures and, to a smaller extent, as arable land. By contrast with natural processes, human activity commonly leads to very fast and drastic environmental changes. Population growth during the Early Middle Ages resulted in increased cropland areas, especially arable land, and the establishment of larger permanent settlements. The deposition of mineral alluvial sediments with plant remains, a younger alluvial soil, was connected with this period.

The profiles described here indicate other effects of human activity. Within the Kb-I and Kb-II profiles, $4 \mathrm{~m}$ thick, the lower part, including lithological units $A$ and $B$, does not contain clearly identifiable stratigraphic hiatuses. Its total thickness is $\sim 2 \mathrm{~m}$ and it lasted from the Early Holocene until the end of the Middle Holocene. The upper interval comprises deposits formed during intensified human activity. The thickness of this profile section is also $\sim 2 \mathrm{~m}$, and contains at least two stratigraphic hiatuses. This interval was deposited over $\sim 3,500$ years. This observation indicates increasing intensity of geological processes, especially fluvial activity, in areas subjected to human activity, via anthropogenic deforestation initiating ablation and slope movements.

Such malacological research may also help reconstruct microhabitats, both locally and regionally, for example to reconstruct the kind of environmental habitat diversity present in the bottom of the Kobylanka Valley during the Middle Holocene.

Acknowledgments. This study was sponsored by $\mathrm{AGH}$ University of Science and Technology through subvention no 16.16.140.315. I also would like to thank Prof. G. Danukalova and an anonymous reviewer for their constructive comments.

\section{REFERENCES}

Alexandrowicz, S.W., 1983. Malacofauna of the Holocene calcareous sediments of the Cracow Upland. Acta Geologica Polonica, 33: $117-158$.

Alexandrowicz, S.W., 1991. Late Quaternary molluscan assemblages of the Będkowska Valley (Cracow Upland). Bulletin of the Polish Academy of Sciences, Earth Sciences, 39: $101-110$.

Alexandrowicz, S.W., 1997. Malacofauna of Holocene Sediments of the Prądnik and Rudawa River Valleys (Southern Poland). Folia Quaternaria, 68: 133-188.

Alexandrowicz, S.W., Alexandrowicz, W.P., 2011. Analiza malakologiczna. Metody badań i interpretacji (in Polish). Rozprawy Wydziału Przyrodniczego PAU, 3: 5-302.

Alexandrowicz, S.W., Alexandrowicz, W.P., Krąpiec, M., Szychowska-Krąpiec, E., 1997. Environmental changes in Southern Poland during historical times (in Polish with English summary). Geologia, Kwartalnik AGH, 23: 339-387.

Alexandrowicz, W.P., 1999. Evolution of the malacological assemblages in North Poland during the Late Glacial and Early Holocene. Folia Quaternaria, 70: 39-69.

Alexandrowicz, W.P., 2004. Molluscan assemblabes of Late Glacial and Holocene calcareous tufas in Southern Poland. Folia Quaternaria, 75: 1-309.

Alexandrowicz, W.P., 2012. Assemblages of molluscs from Sulisławice (Małopolska Upland, southern Poland) and their significance for interpretation of depositional conditions of calcareous tufas in small water bodies. Annales Societatis Geologorum Poloniae, 82: 161-176.
Alexandrowicz, W.P., 2013a. Malacological sequence from profile of calcareous tufa in Groń (Podhale Basin, southern Poland) as an indicator of the Late Glacial/Holocene boundary. Quaternary International, 293: 196-206.

Alexandrowicz, W.P., 2013b. Late Glacial and Holocene molluscan assemblages in deposits filling palaeolakes in Northern Poland. Studia Quaternaria, 30: 5-17.

Alexandrowicz, W.P., 2013c. Molluscan communities in Late Holocene fluvial deposits as an indicator of human activity: a study in Podhale Basin in Southern Poland. Ekologia, Bratislava, 32: 111-125.

Alexandrowicz, W.P., 2015. The application of malacological analysis in the study of slope deposits: Late Pleistocene and Holocene of the Podhale Basin (Carpathians, Poland). Acta Geologica Polonica, 65: 245-261.

Alexandrowicz, W.P., 2019a. Malacological evidence of the natural and anthropogenic changes of the environment in the eastern part of the Carpathian Foreland: the studies in the Glinne stream valley near Rzeszów (southern Poland). Carpathian Journal of Earth and Environmental Sciences, 14: 367-384.

Alexandrowicz, W.P., 2019b. Record of environmental changes and fluvial phases in the Late Holocene within the area of Podhale (the Carpathians, southern Poland): studies in the Falsztyński valley. Geological Quarterly, 63 (4): 629-642.

Alexandrowicz, W.P., 2020. Development of settlements in Podhale Basin and Pieniny Mts. (western Carpathians, southern Poland) in light of malacological research. Carpathian Journal of Earth and Environmental Sciences, 15: 247-259. 
Alexandrowicz, W.P., Rybska, E., 2013. Environmental changes of intermontane bains derived from malacological analysis of profile of calcareous tufa in Niedzica (Podhale Basin, Southern Poland). Carpathian Journal of Earth and Environmental Sciences, 8: 13-26.

Alexandrowicz, W.P., Szymanek, M., Rybska, E., 2014. Changes to the environment of intramontane basins in the light of malacological research of calcareous tufa: Podhale Basin (Carpathians, Southern Poland). Quaternary International, 353: 250-265.

Alexandrowicz, W.P., Szymanek, M., Rybska, E., 2016. Molluscan assemblages from Holocene calcareous tufa and their significance for palaeoenvironmental reconstructions. A study in the Pieniny Mountains (Carpathians, southern Poland). Carpathian Journal of Earth and Environmental Sciences, 11: 37-54.

Alexandrowicz, Z., Alexandrowicz, W.P., Buczek, K., 2019. Conservation of the Natura 2000 Areas in the Context of Environmental Changes in Past and Present: a Case from the Polish Carpathians Geoheritage. Geoheritage, 11: 517-529.

Broda, J., 1985. The deforestation process on Polish territory since prehistoric times. (in Polish with English summary). Czasopismo Geograficzne, 56: 151-172.

Bronk Ramsey, C., 2003. OxCal Program 3.9. University of Oxford. Radiocarbon Accelerator Unit.

Čiliak, M., Čejka, T., Šteffek, J., 2015. Molluscan diversity in stream driftwood: relation to land use and river section. Polish Journal of Ecology, 63: 124-134.

Dabkowski, J., 2020. The late-Holocene tufa decline in Europe: Myth or reality? Quaternary Science Reviews, 230: 106-141.

Davišek, J., Hájek, M., Jamrichová, E., Libor, P., Večeřa, M., Tichý, L., Willner, W., Horsák, M., 2020. Holocene matters: Landscape history accounts for current species richness of vascular plants in forests and grasslands of eastern Central Europe. Journal of Biogeography, 47: 721-735.

Dobrowolski, R., Pidek, I.A., Alexandrowicz, W.P., Hałas, S., Pazdur, A., Piotrowska, N., Buczek, A., Urban, D., Melke, J., 2012. Interdisciplinary studies of spring mire deposits from Radzików (South Podlasie Lowland, East Poland) and their significance for palaeoenvironmental reconstructions. Geochronometria, 39: 10-29.

Dobrowolski, R., Bałaga, K., Buczek, A., Alexandrowicz, W.P., Mazurek, M., Hałas, S., Piotrowska, N., 2016. Multi-proxy evidence of Holocene climate variability in Volhynia Upland (SE Poland) recorded in spring-fed fen deposits from the Komarów site. The Holocene, 26: 1406-1425.

Dobrowolski, R., Mazurek, M., Osadowski, Z., Alexandrowicz, W.P., Pidek, I.A., Pazdur, A., Piotrowska, N., Drzymulska, D., Urban, D., 2019. Holocene environmental changes in northern Poland recorded in alkaline spring-fed fen deposits - a multi-proxy approach. Quaternary Science Reviews, 219: 236-262.

Gedda, B., 2001. Environmental and climatic aspects of the Early and Mid Holocene calcareous tufa and land mollusc fauna in southern Sweden. Lundqua Thesis, 45: 1-50.

Gedda, B., 2006. Terrestrial mollusc succession and stratigraphy of a Holocene calcareous tufa deposit from the Fyledalen valley, southern Sweden. The Holocene, 16: 137-147.

Giesecke, T., Brewer, S., Finsinger, W., Leydet, M., Bradshaw, R.H.W., 2017. Patterns and dynamics of European vegetation change over the last 15,000 years. Journal of Biogeography, 44: 1441-1456.

Goudie, A., Viles, H.A., Pentecost, A., 1993. The late-Holocene tufa decline in Europe. The Holocene, 3: 181-186.

Gradziński, M., Hercman, H., Rizzi, M., Stachowicz-Rybka, R., Stworzewicz, E., 2017. Sedimentation of Holocene tufa influenced by the Neolithic man: an example from the Sąspowska Valley (southern Poland). Quaternary International, 437: 71-83.

Granai, S., Limondin-Lozouet, N., 2018. The Holocene expansion of grassland in northern Europe reconstructed from molluscan assemblages. Boreas, 47: 768-779.

Groom, P., Schlee, D., Hughes G., Crane, P., Ludlow, N., Murphy, K., 2011. Two early medieval cemeteries in Pambrokeshire:
Brownslade Borrow and West Angle Bay. Archaeologia Cambrensis, 160: 133-203.

Hammer, Ľ., Harper, D.A.T., Ryan, P.D., 2001. Past: paleontological statistics software package for education and data analysis. Palaeontologica Electronica, 4: 1-9.

Horáčková, J., Ložek, V., Juřičková, L., 2015. List of malacologically treated Holocene sites with brief review of palaeomalacological research in Czech and Slovak Republics. Quaternary International, 357: 207-211.

Horsák, M., Juřičková, L, Picka, J., 2013. Molluscs of the Czech and Slovak Republics. Kabourek, Zlín.

Horsák, M., Limondin-Lozouet, N., Juřičková, L., Granai, S., Horáčková, J., Legentil, C., Ložek, V., 2019. Holocene succession patterns of land snails across temperate Europe: East to west variation related to glacial refugia, climate and human impact. Palaeogeography, Palaeoclimatology, Palaeoecology, 524: 13-24.

Jäger, K.D., Ložek, V., 1983. Paleohydrological implications on the Holocene development of climate in Central Europe based on depositional sequences of calcareous fresh-water deposits. Quaternary Studies in Poland, 4: 81-89.

Juřičkova, L., Horsák, M., Horáčková, J., Ložek, V., 2014a. Ecological groups of snails - use and perspectives. European Malacological Congress, Cambridge, UK, poster. (www. http://mollusca.sav.sk/malacology/Jurickova/2014-ecological-groups-poster.pdf).

Juřičková, L., Horáčková, J., Ložek, V., 2014b. Direct evidence of Central European forest refugia during the Last Glacial Period based on mollusc fossils. Quaternary Research, 82: 222-228.

Keen, D.H., 1990. Significance of the record provided by Pleistocene fluvial deposits and their included molluscan faunas for palaeoenvironmental reconstruction and stratigraphy: case studies from the English Midlands. Palaeogeography, Palaeoclimatology, Palaeoecology, 80: 25-34.

Krolopp, E., Sümegi, P., 1993. Vertigo modesta (Say 1924), Vertigo geyeri Lindholm 1925 and Vertigo genesii (Gredler 1856) species in Pleistocene formations of Hungary. Malacological Newsletter, 12: 9-14

Kruk, J., Alexandrowicz, S.W., Milisauskas, S., Śnieszko, Z., 1996. Environmental changes and settlement on the loess uplands. An archaeological and palaeogeographical study on the Neolitic in the Nidzica basin (in Polish with English summary). Instytut Archeologii i Etnografii PAN, Kraków.

Kruk, J., Milisauskas, S., 1999. The rise and fall of Neolithic societies. Instytut Archeologii i Etnologii PAN, Kraków.

Lewandowski, J., 2015. Kenozoik regionu Śląsko-Krakowskiego (in Polish). Wydawnictwo Uniwersytetu Śląskiego, Katowice.

Limondin-Lozouet, N., 1992. Biogeographie Holocene de Vertiginidae (Mollusca - Gastropoda) Europeens: relations la derniere deglaciation. Comptes Rendus de l'Académie des Sciences Paris, 315: 1281-1287.

Ložek, V., 1964. Quartärmollusken der Tschechoslovakei. Rozpravy Ustředniho Ustavu Geologického, 31: 1-374.

Madeyska, T., 1982. The stratigraphy of Palaeolithic sites of the Cracow Upland. Acta Geologica Polonica, 32: 227-242.

Mauri, A., Davis, B.A.S., Kaplan, J.O., Collins, P., 2015. The climate of Europe during the Holocene: a gridded pollen-based reconstruction and its multi-proxy evaluation. Quaternary Science Reviews, 112: 109-127.

Mayewski, P.A., Rohling, E.E., Stager, J.C., Karlen, W., Maasch, K.A., Meeker, L.D., Meyerson, E.A., Gasse, F., van Kreveld, S., Holmgren, K., Lee-Thorp, J., Rosqvist, G., Rack, F., Staubwasser, M., Schneider, R.R., Steig, E.J., 2004. Holocene climate variability. Quaternary Research, 62: 243-255.

Meyrick, R.A., 2001. The development of terrestrial mollusc faunas in the 'Rheinland region' (western Germany and Luxembourg) during the Lateglacial and Holocene. Quaternary Science Reviews, 20: 1667-1675.

Meyrick, R.A., 2002. Holocene molluscan faunal history and environmental change at Kloster Mühle, Rheinland-Pfalz, western Germany. Journal of Quaternary Sciences, 18: 121-132. 
Meyrick, R.A., Preece, R.C., 2001. Molluscan successions from two Holocene tufas near Northampton, English Midlands. Journal of Biogeography, 28: 77-93.

Morisita, M., 1959. Measuring of interspecific association and similarity between communities. Memories of the Faculty of Sciences, Kyushu University, E, 3: 65-80.

Moskal-del Hoyo, M., Mueller-Bieniek, A., Alexandrowicz, W.P., Wilczynski, J., Wędzicha, S., Kapcia, M., Przybyła, M.M., 2017. The continuous persistence of open oak forests in the Miechów Upland (Poland) in the second half of the Holocene. Quaternary International, 458: 14-27.

Moskal-del Hoyo, M., Wacnik, A., Alexandrowicz, W.P., Stachowicz-Rybka, R., Wilczyński, J., Pospuła-Wędzicha, S., Szwarczewski, P., Korczyńska, M., Cappenberg, K., Nowak, M., 2018. Open country species persisted in loess regions during the Atlantic and early Subboreal phases: New multidisciplinary data from southern Poland. Revue of Palaeobothany and Palynology, 253: 49-6.

Pedley, H.M., 1990. Classification and environmental models of cool freshwater tufas. Sedimentary Geology, 68: 143-154.

Pedley, H.M., 2009. Tufas and travertines of the Mediterranean region: a testing ground for freshwater carbonate concepts and developments. Sedimentology, 56: 221-246.

Pokryszko, B., 1990. The Vertiginidae of Poland (Gastropoda: Pulmonata: Pupillidae) - a systematic monograph. Annales Zoologici, 43: 133-257.

Rousseau, D.-D., Limondin, N., Puissegur, J.-J., 1993. Holocene environmental signals from mollusk assemblages in Burgundy (France). Quaternary Research, 40: 237-253.

Roberts, N., Fyfe, R.M., Woodbridge, J., Gaillard, M.-J., Davis, B.A.S., Kaplan, J.O., Marquer, L., Mazier, F., Nielsen, A.B., Sugita, S., Trondman, A.-K., Leydet, M., 2018. Europe's lost forests: a pollen-based synthesis for the last 11,000 years. Scientific Reports, 8: 1-8.

Rutkowski, J., 1989. Geological structure of the Cracow region, South Poland (in Polish with English summary). Przegląd Geologiczny, 37: 302-308.

Rutkowski, J., Starkel, L., 1989. Influence of the human economy on geological processes in the Cracow region, South Poland (in
Polish with English summary). Przegląd Geologiczny, 37: 312-318.

Schenková, V., Horsák, M., 2013. Refugial populations of Vertigo lilljeborgi and V. genesii (Vertiginidae): new isolated occurrences in Central Europe, ecology and distribution. American Malacological Bulletin, 31: 323-329.

Starkel, L., 1997. The evolution of fluvial systems in the Upper Vistulian and Holocene in the territory of Poland. Landform Analysis, 1: 7-18.

Starkel, L., Michczyńska, D.J., Krąpiec, M., Margielewski, W., Nalepka, D., Pazdur, A., 2013. Progress in the Holocene chrono-climatostratigraphy of Polish territory. Geochronology, 40: 1-21.

Szymanek, M., Krajcarz, M., Krajcarz, M.T., Alexandrowicz, W.P., 2016. Holocene palaeoecological changes recorded in mollusc-bearing cave sediments, the Cave above the Słupska Gate (southern Poland). Geologica Acta, 14: 261-282.

Väliranta, M., Salojärvi, N., Vuorsalo, A., Juutinen, S., Korhola, A., Luoto, M., Tuittila, E.-S., 2016. Holocene fen-bog transitions, current status in Finland and future perspectives. The Holocene, 27: 752-764.

Walczak, W., 1956. Quaternary deposits and morphology of the southern part of the Cracow Jura in the Będkówka and Kobylanka basin (in Polish with English summary). Biuletyn Instytutu Geologicznego, 100: 419-461.

Walker, M., Head, M. J., Lowe, J., Berkelhammer, M., Björck, S., Cheng, H., Cwynar, L. C., Fisher, D., Gkinis, V., Long, A., Newnham, R., Rasmussen, S.O., Weiss, H., 2019. Subdividing the Holocene Series/Epoch: formalization of stages/ages and subseries/subepochs, and designation of GSSPs and auxiliary stratotypes. Journal of Quaternary Science, 34: 173-186.

Walter-Schultes, F., 2012. European non-marine molluscs, a guide for species identification. Planet Poster Editions, Göttingen.

Wiktor, A., 2004. Ślimaki lądowe Polski (in Polish). Wydawnictwo Mantis, Olsztyn.

Žak, K., Ložek, V., Kadlec, J., Hladikova, J., Cilek, V., 2002. Climate-inducted changes in Holocene calcareous tufa formations, Bohemian Karst, Czech Republic. Quaternary International, 91: 137-152. 